\title{
THE ELEMENTS OF SUSTAINABLE DEVELOPMENT: PRINCIPLES OF IN- TEGRATION AND SUSTAINABLE UTILIZATION
}

\author{
Andri G.Wibisana* \\ Environmental Law Department, Faculty of Law,University of Indonesia, Jakarta \\ Depok, West Java, 16424
}

\section{Intisari}

Sustainable development is development that meets the needs of the present without compromising the ability of future generations. However, that concept lacks of clarity, which leads to various interpretations. Scholars have argued that the definition of sustainable development can be explained into four elements, namely the integration principle, sustainable use, intra-generational equity, and inter-generational equity. It analyses the elements of integration and sustainable using both legal and non-legal perspectives and shows how the elements have been recognized in various legal documents, while finds that various international commitments have indicated the growing concerns for conservation and sustainable use of natural resources.

Keywords: sustainable development, integration principle, natural resources.

\section{Intisari}

Pembangunan berkelanjutan adalah pembangunan untuk memenuhi kebutuhan generasi sekarang tanpa mengganggu kemampuan generasi yang akan datang. Definisi pembangunan berkelanjutan dibagi menjadi 4 (empat), yaitu prinsip integrasi, pemanfaatan secara berkelanjutan, keadilan intra generasi, dan keadilan antar generasi. Artikel ini menganalisis prinsip integrasi dan pemanfaatan berkelanjutan. Artikel ini memandang bahwa prinsip integrasi harus diinterpretasikan dalam kerangka perlindungan lingkungan, sehingga memperoleh prioritas guna menyeimbangkan antara kebutuhan perlindungan lingkungan dengan kebutuhan akan pembangunan. Di samping itu, meskipun terdapat berbagai penafsiran mengenai pemanfaatan berkelanjutan, namun pengakuan tentang pemanfaatan berkelanjutan cukup untuk menunjukkan adanya peningkatan perhatian terhadap pemanfaatan berkelanjutan atas sumber daya lingkungan.

Kata Kunci: pembangunan berkelanjutan, prinsip keterpaduan, sumber daya lingkungan.

\section{Pokok Muatan}

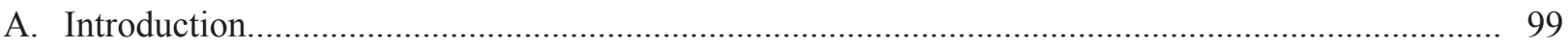

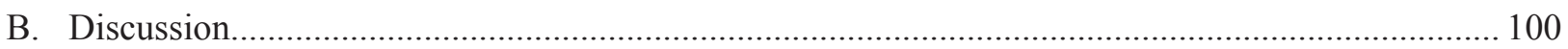

1. Integration Principle

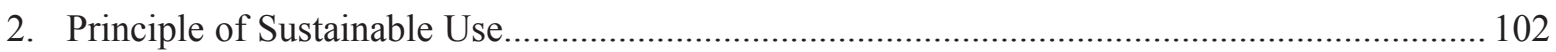

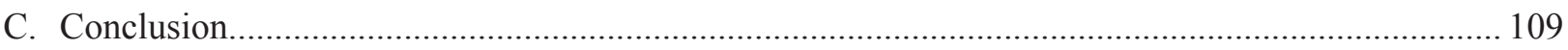

Correspondence address: mragw@yahoo.com/andri.gunawan@ui.ac.id 


\section{A. Introduction}

The concept of Sustainable Development is not a concept that appears instantaneously, but it is the output by long debating process between the need for development and the awareness of the importance of environmental protection. In 1983, The United Nations General Assembly created an agency in charge of reviewing some of the important issues related to the development, the environment, and the formulation of innovative, concrete, and realistic steps to overcome the problems. The institute was named the World Commission on Environment and Development (WCED)-or often referred to as the Brundtland Commission.

In 1987, WCED issued a report entitled "Our Common Future". This commission was not a commission that found the term Sustainable Development, although it is popularized by this commission and put it in the center of international policy-making. The Commission defined sustainable development as "development that meets the needs of the present without compromising the ability of future generations to meet their own needs". ${ }^{1}$

According to the explanation of Commission, the definition above contains two elements: the element of needs and elements of limitations. Based on the element of needs, the Commission considered that the needs are particularly their poor's need, which should be a priority of the needs accomplishment. While the limitation elements, the Commission interpreted it as the limited ability of the environment, which is created by the technological conditions and social organization, to fulfil the present and future generation's needs. In this case, the Commission stated: ${ }^{2}$
Sustainable development is development that meets the needs of the present without compromising the ability of future generations to meet their own needs. It contains within it two key concepts, namely: Firstly, the concept of 'needs', in particular the essential needs of the world's poor, to which overriding priority should be given; and Secondly, the idea of limitations imposed by the state of technology and social organization on the environment's ability to meet present and future needs.

Sustainable development, based on the quotation above, it can be descended into a few core elements, namely: integration principle, sustainable use, principle of intra generation justice (intra-generational equity), and principle of inter generation justice (intergenerational equity). ${ }^{3}$ Integration elements can be concluded from the recognition of the need for development, but on the other hand is also acknowledged that fulfilling the needs of this development should not interfere with the ability of future generations to fulfil their needs. Elements of the sustainable use can be seen from the recognition to the impact of technology and social organization on the environment's ability to fulfil the needs of current and future generations, as well as the recognition that the development in process still considers the interests of future generations. Intra-generation equity element can be seen from the word definition of needs which gives priority to fulfil the needs of poor communities. While the element of inter generations equity can be inferred from the recognition of the balance between the needs of the present generation with the needs of future generations

This article aims to further discuss the main

\footnotetext{
Sharon Beder, 2006, Environmental Principles and Policies: An Interdisciplinary Introduction, Routledge, London, p. 18

World Commission on Environment and Development, 1987, Report of the World Commission on Environment and Development: Our Common Future, Report, Ch.2, par.1.

These elements also proposed by Sands, who states that law element from sustainable development consist of: (a) the justice of inter-generation (intergenerational equity), which can see from the need that protects natural resources for the benefit of future generations; (b) sustainable use (the principle of sustainable use), which is reflected in the exploitation of natural resources sustainably (sustainable), caution (prudent), rational, wise, and appropriate; (c) intra-generation equity, which is shown through the use of natural resources equitably (equitable use of natural resources), where the utilization of natural resources by the state should consider the needs of other countries, and (d) the principle of integration (integration principle), which called for a guarantee. That environmental consideration will be integrated into the plan, policy, and program which relate to economic and development, and the acquirement of development needs should pay attention to the purpose of environmental protection. Philippe Sands, 1995, Principles of International Environmental Law, Vol. 1, Frameworks, Standards, and Implementation, Manchester University Press, Manchester, p. 199. Similar elements are also expressed by Magraw and Hawke stated that the elements of sustainable development consist of: intra-generation equity, intergenerational equity, the principle of integration, and the environment need to be preserved at least to a significant degree. See Daniel Barstow Magraw and Lisa D. Hawke, "Sustainable Development", in Daniel Bodansky, Jutta Brunnée, and Ellen Hey (Eds.), 2007, The Oxford Handbook of International Environmental Law, Oxford University Press, Oxford, p. 619 .
} 
elements of sustainable development, both from legal and non-legal perspective, especially economic perspective. For a discussion of the legal perspective, this article will explain how environmental law gives the interpretation of each element of sustainable development. In this case, the article will focus the discussion on the elements of integration and sustainable use.

After this introduction section, in Part 2 will discuss the integration principle. In this context, this paper does not look at the integration principle as a principle that gives equal quality to all interests, but the principles that contains a priority for ecological protection efforts. Furthermore, the section 3 will discuss sustainable use. This paper will look at the idea of sustainable utilization adopted by various legal documents, and how the concept of sustainable use has various interpretations of sustainable development itself. Section 4 presents some conclusions.

\section{B. Discussion}

\section{Integration Principle}

The principle of integration is the backbone of sustainable development. ${ }^{4}$ According to Sands, this principle is a commitment to integrate the environmental considerations into development, and to consider the need for economic and social development in the preparation of environmental liabilities. This principle can be used as the basis for the existence of environmental recruitments (green conditionality) in relief; determination of the legal commitment by contributing countries, including the economic benefits for all this time (historic responsibility of states, Including the resulting economic benefits), and the determination of the capacity of countries in the responding of obligations regarding the protection of the environment. ${ }^{5}$

The definition of integration principle has begun by referring to the Rio Declaration which states that "in order to Achieve sustainable development, environmental protection shall constitute an integral part of the development process and cannot be Considered in isolation from it". ${ }^{6}$ From this quote, it can be seen that the first demands of the integration principle has the certainty that environmental protection is an integral part of the development process. Thus, it can be concluded that the integration principle in the context of sustainable development requires the state to ensure that its economic and social interests will not ignore the environmental considerations. On the other hand, environmental protection efforts are taken to consider the social and economic that might have impacts.

Meanwhile, ICJ interpreted the function of integration as a tool for connecting and balancing of various interests and principles which may be in contradiction that is the development with the interests of environmental protection. It can be seen from the Perspectives of Weeramantry and Trindade. $^{7}$ By the application of the principle of development on the court decisions, in this case, then we can see how the integration elements of sustainable development have provided guidance to the courts to reconcile the principles and different interests, even conflicting.

However, it is necessary to explain more about the function of balance and reconciliation of the integration principle. According to Osofsky, integration as a balance function in the various interests is still insufficient. Osofsky considers that since 2000, Johannesburg Declaration has recognized that both the concept of economic development on the one hand and the development envi-

Christina Voigt, 2009, Sustainable Development as a Principle of International Law: Resolving Conflicts between Climate Measures and WTO Law, Martinus Nijhoff Publishers, Leiden, p. 37. However, different opinions expressed by Marong who refused to take integration as a separate principle. According to him, the integration is a methodological instrument for implementing sustainable development. In this case Marong states “[a]long the same lines, I do not approach 'integration' as a separate principle, but as a methodological instrument that enables decision-makers to make a transition from a sector-based (environment versus development; trade versus environment), to a more holistic approach in development planning". Alhaji B.M. Marong, "From Rio To Johannesburg: Reflections on the Role of International Legal Norms in Sustainable Development", Georgetown International Environmental Law Review, Vol. 16, 2003, pp. 62-63

Philippe Sands, Op.cit, pp. 205-206.

4th Principle of Rio Declaration, Doc. A/CONF.151/26 (Vol. I), 31 ILM 874 (1992) (hereinafter called Rio Declaration).

Weeramantry, in his dissenting opinion to the case Gabcikovo - Nagymaros (Hungary v. Slovakia), states that sustainable development is not only a concept, but it is a normative legal principle. Without this legal principle, then Gabcikovo - Nagymaros case would be very difficult to decide. He said, "[...] I consider it to be more than a mere concept, but as a principle with normative value which is crucial to the determination 
ronment on the other hand, contains a thorough not understanding. Consider that the greatest challenge to the realization of sustainable development is the issue of poverty, the concept of development should be in reorientation towards social development. ${ }^{8}$ From this description, it appears that for Osofsky, the integration principle is not sufficient if it merely seen as a function of balance between the interests of economic development to the benefit of the development environment. Moreover, based on perspective of Osofsky, integration of sustainable development elements provides the impetus for change in the orientation of development, of economic development and on the other hand the development of environment becomes a social development with an emphasis on poverty alleviation.

Nevertheless, it can be said that social development remains to be placed in the framework of sustainable development. Because of this perspective, the principle of integration has important meaning to change the perspective of development, from anthropocentrism to ecocentrism. This opinion is in line with the views of the IUCN contained in World Conservation Strategy, as referred by Meyers and Muller. This view sees that the concept of development requires a new ethic, which is not only focusing on human survival, but also puts the interests of humans in harmony with nature. ${ }^{9}$ Meyers and Muller further argues that this ethical changes must explain what behaviour is acceptable and what is not received, related to the human relationship with nature. In this case, Meyers and Muller saw that the construction of this new ethic has at least three characteristics. First, it must be able to maintain the essential ecological and life supporting system. Second, it must be able to protect the ethics of genetic diversity. Third, this ethic should be able to provide guidance on the sustainable use of ecosystems. ${ }^{10}$ In other words, Meyers and Muller stated that "the principal ethical implication of adherence to the precepts of ecologically sustainable development is the recognition that human beings are not the center of life on Earth." 11 Ethics like this will lead to a redefinition of the human lies in conjunction with nature. Not only humans can be placed at the center of all the objectives of the

of this case. Without the benefits of its insights, the issues involved in this case would have been difficult to resolve". See Case Concerning the Gabcikovo-Nagymaros Project (Hungary v. Slovakia): Separate Opinion of Vice-President Weeramantry, 1997 ICJ 7 (hereinafter called Gabcikovo-Nagymaros Case: Weeramantry's opinion), p. 90. In this case, Weeramantry knew that the case of Gabcikovo-Nagymaros showed the existence of different interests, namely the need of development in one side (in case of Slovakia interest) and the need of environmental protection in another side (in case of Hungaria interest). In the view of Weeramantry, the law principle that can connect these two contradictory needs is the sustainable development needs. Case of Gabcikovo-Nagymaros: Weeramantry opinion, p. 88. Meanwhile, Judge Trindade, in his dissenting opinion for cases of Pulp Mils on the River Uruguay (Argentina v. Uruguay) basically agreed that sustainable development serves to bridge the interests of development on the one hand, and the interests of environmental protection on the other. In this context, Trindade stated : "[s] ustainable development came to be perceived, furthermore, as a link between the right to a healthy environment and the right to development; environmental and developmental considerations came jointly to dwell upon the issues of elimination of poverty and satisfaction of basic human needs". See Case Concerning Pulp Mills on the River Uruguay (Argentina v. Uruguay), Separate Opinion of Judge Cançado Trindade, 2010, http://www.icj-cij.org/docket/files/135/15885.pdf, (next is called as the case of Pabrik Kertas Sungai Uruguay: Trindade's opinion), p. 132.

Meanwhile, the norm conciliator/this balancer by Lowe interpreted as filler features (interstitial norm) of sustainable development. In this case, as described by Fitzmaurice Lowe, reject the Weeramantry's view state that sustainable development is a legal principle that has been normative. For Lowe, sustainable development is not a rule of law, because the sustainable development does not have the normativity. Can be said to possess the normativity, a concept must be expressed in a normative language. According to Lowe, because the sustainable development cannot be poured into the normative language, then sustainable development does not have " a fundamentally norm-creating character". See Malgosia Fitzmaurice, 2009, Contemporary Issues in International Environmental Law, Edward Elgar, Cemberley, p . 80. Furthermore, Lowe sees that sustainable development is only a meta - principle that serves to reconcile some contradictory principles. In this case, Lowe thinks that the function of this meta - principle is "interstitial activity, pushing and pulling the boundaries of true primary norms when they threaten to overlap or conflict with each other". Ibid., pp. 80-81. However, it necessary was expressed here that neither view Weeramantry nor Lowe above equally shows the role of sustainable development to provide direction to or change the view from the decision makers above the interest or pre-existing norms. Integration Element of sustainable development who has a major position is as provider direction or modifiers view of the decision makers.

$8 \quad$ Hari M. Osofsky, "Defining Sustainable Development After Earth Summit 2002", Loyola of Los Angeles International \& Comparative Law Review, Vol. 26, 2003, p. 123-124.

9 IUCN states that "Ultimately the behaviour of entire societies towards the biosphere must be transformed if the achievement of the conservation objective is to be assured. A new ethic, embracing plants and animals as well as people is required for human societies to live in harmony with the natural world on which they depend for survival and well being". See Gary D. Meyers dan Simone C. Muller, "The Ethical Implications, Political Ramifications and Practical Limitations of Adopting Sustainable Development as National and International Policy", Buffalo Environmental Law Journal, Vol. 4, 1996, p. 36.

$10 \quad$ Ibid., p. 37.

11 Ibid., pp. 37-38. 
activity, but also the humanity of each individual is determined by the individual ecology's relationship with the nature. In this context, the efforts of environmental protection do not intend solely for the benefit of humans. Moreover, all these safeguards go beyond mere human interests, and cover the interests of the community of all beings which one of them is human.

Another important point related to the principle of integration is that this principle should be put in a frame or a priority in form of protection to essential ecosystems. In this context, the opinion expressed by Voigt is very important to note. Voigt rejected the notion that in defining sustainable development as a balance function (balancing norm) that equal portion should be given to all interests. For Voigt, in absence of conceptual clarity for sustainable development, hence giving the equal portion to each interest is an illusion. According to Voigt, although the integration function requires a respect for every interest, but respect must be placed within a framework of priority based on ecological thresholds. It means that before the balancing performed, each country needs to set ecology boundaries to ensure no disruption of important functions irreplaceable environment. ${ }^{12}$ Thus, protection against irreplaceable and essential natural functions that should be the purpose and basis of action be equally done, because the survival of the ecosystem, in which human become members, will depend on the integrity of environmental functions are essential and irreplaceable.

In addition to functioning as a counterweight norm as described above, the integration element also serves as a unifying norms of other elements of sustainable development, especially the elements of intra-generation equity and fairness between generations. In this case, Barral states: ${ }^{13}$

It is only when they [intra dan intergenerational equity-writer] are read together that the set principles confer on the expression 'sustainable development' its specificity. Development will be sustainable only when both intergenerational (environmental protection) and intra generational (fair economic and social development) equity are guaranteed, and this is to be achieved through the integration.

From the quote above, it can be concluded that sustainable development can be realized only if there is a guarantee of intra and inter-generational equity, and the justice principle will only be achieved through the integration of elements of sustainable development. In this context, a formula that gives Barral: Sustainable Development $=($ intra-generation equity + equity between generations) $\mathrm{x}$ integration. ${ }^{14}$

\section{Principle of Sustainable Use}

This section will be presented by way of what sustainable use interpreted in several international documents. On the other hand, this section will also show how economically sustainable use of the meaning is related to the debate about the meaning of sustainability itself.

\section{a) Sustainable Use in The Legal Per- spective}

At first, the term used to refer to the efforts of environmental protection and natural resource is conservation terms. In the past, the need for conservation is also only occur if there has been a threat to a species, either in the form of extinction threats or reduced availability seriously. ${ }^{15}$ During its development, then conservation is considered essential in order to achieve sustainability, without the need to relate them to the extinction threat or depletion of natural resources. For example, the World Charter of Naturein 1982, as quoted by Birnie, et al., stating that conservation principles should be applied to all areas on Earth to achieve optimum sustainable productivity that does not harm the

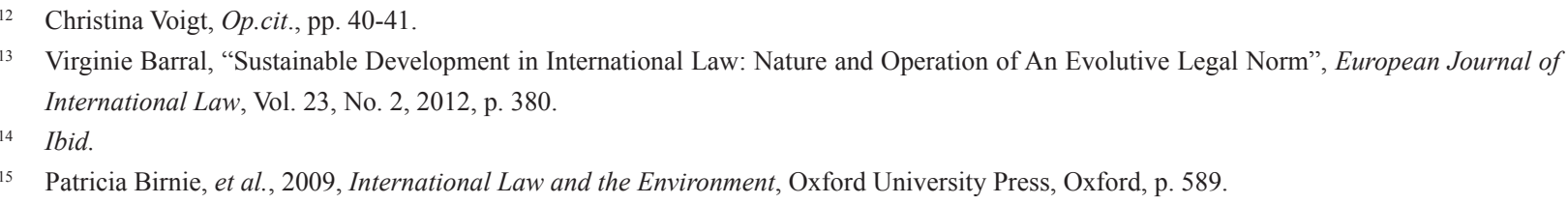


ecosystem. To achieve these objectives, the use of natural resources without exceeding the resource capacity to regenerate and without causing any environmental impacts that cannot be restored (irreversible damage). ${ }^{16}$

The linkage between conservation and sustainable use can be seen, for example, in the Convention on Biological Diversity (CBD). The CBD states that the purpose of this Convention is the conservation of biodiversity, the use of these resources in a sustainable manner and the sharing of benefits from the utilization of a fair. ${ }^{17}$ In this case, the sustainable use is defined as the utilization of biological resources and the manner in which the utilization rate in the long term will not lead to a decrease in biodiversity, so as to maintain the biodiversity resource potential to fulfil the needs of the present generation and the future generation. ${ }^{18}$ Although the CBD does not define what is meant by the conservation, but this convention determines what efforts are necessary to ensure the conservation and sustainable use of biological resources. For example, in general the CBD explains that each state has the responsibility to develop a strategy on the one hand, plans, and programs of conservation and sustainable use of biological resources; being on the other side to integrate the conservation and sustainable use into plans, programs, and sectoral or cross-sectoral policies of each country. ${ }^{19}$

Nevertheless, it must be stressed here that some conventions or documents use the other terms which are not the term "sustainable use". For example, the Technical Meeting Rome 1955, as a precursor of the Geneva
Conference of UNCLOS I in 1958, has been interpreted that the conservation objectives as attempt are to achieve maximum sustainable results (maximum sustainable yield- MSY). In this case, MSY is often interpreted as a collection of maximum stock, while keeping the maintenance of the average stock. To get the conservation purposes, then MSY wants the stock to only be taken at the most number of new reserves into the entry level in the stock of natural resources. ${ }^{20}$ By taking such a way that takes into account the level of regeneration of these natural resources, the availability of natural resources can be guaranteed.

In its development, MSY is no longer considered adequate as a conservation purpose. This is because MSY consideration is not paying attention to the economy of natural resource use, and also does not pay attention to the ecological relationship between natural resource habitat, habitat quality, and disturbance to habitat, or even loss of habitat. Therefore, some parties suggested that conservation objectives are transformed into optimum yield, whose level is set tighter than the MSY. Meanwhile, other alternatives which are also offered in lieu of MSY are the optimum population, optimum sustainable population level, the result of economic optimum or maximum economic yield, or the optimum level of the ecological resource management. ${ }^{21}$

Meanwhile, the Ramsar Convention in Wetlands 1971 on conservation associates conservation effort with the wise use. In this case, the Ramsar Convention states that "the Contracting Parties shall formulate and im-

$6 \quad$ Ibid., p. $199 .$.

17 The Purposes of CBD is: "The objectives of this Convention, to be pursued in accordance with its relevant provisions, are the conservation of biological diversity, the sustainable use of its components and the fair and equitable sharing of the benefits arising out of the utilization of genetic resources, including by appropriate access to genetic resources and by appropriate transfer of relevant technologies, taking into account all rights over those resources and to technologies, and by appropriate funding". See, Article 1 Convention on Biological Diversity (1760 UNTS 79, 31 ILM 818 (1992).

8 Article 2 Convention on Biological Diversity (1760 UNTS 79, 31 ILM 818 (1992).

Article 6 Convention on Biological Diversity (1760 UNTS 79, 31 ILM 818 (1992)..

Patricia Birnie, et al., Op.cit., pp. 590-591.

Ibid., p. 591. 
plement their planning so as to promote the conservation of the wetlands included in the List, and as far as possible the wise use of wet $\underline{\text { lands }}$ in their territory"-[additional authors underscore].22 During its development, COP 3 of the Ramsar Convention held in Regina, Canada, in 1987 has adopted the definition of "wise use" defined as land use in a sustainable manner for the benefit of mankind in a way that is appropriate for the maintenance of the nature of the ecosystem. ${ }^{23}$ While the use of the sustainable utilization is defined by COP 3 as the use of people over the biggest wetlands that produce benefits for the current generation, while maintaining the ability of wetlands to meet the needs of future generations. ${ }^{24}$ Furthermore, the Ramsar Convention COP 9, held in Kampala, Uganda, in 2005, has adopted the definition of "wise use" which is used by the Millennium Ecosystem Assessment, which the definition is the capability of maintaining the utilization of ecological character (ecological character) of wet lands, which is achieved through the implementation of various ecosystem approach in the context of sustainable development. ${ }^{25}$ While the ecological character is defined as a combination of components, processes and benefits/services that characterize an ecosystem of wetlands in a particular period. ${ }^{26}$ From this development, it appears that initially only the Ramsar Convention firstly associate only with the wise use; but later in its development, a meeting of the parties of the
Convention definition of wise use formulation associate with sustainable utilization.

The extent to which international law has determined the liability for the conservation effort and sustainable use, of course, cannot be determined at this time. In fact, even the terms used were different. In addition, except in the case of the management of fisheries and aquatic resources, not many conventions that have been able to develop a regime that is specific enough to apply the concept of sustainable use. On the other hand, each country still holds the greatest authority and discretion in interpreting the conservation and sustainable use. ${ }^{27}$

Nevertheless, the state's discretion to translate their conservation policies is not without limits. However, every state bounded by the obligations not to abuse the right (abuse of right). This obligation has been recognized as a principle of international environmental law, which is then poured in Principle 21 of the Stockholm Declaration and Principle 2 of the Rio Declaration. In essence, the both declaration states that although it has the right and authority to manage its resources in accordance with environmental policies and their development, each state also has a responsibility ensure that the utilization of natural resources in their area is not causing harm to another country or region areas outside its jurisdiction.

On the other hand, as revealed by Birnie, et al., Commitments and interna-

22 Article 3 Paragraph 1, 1971 Ramsar Convention (996 U.N.T.S. 245, 11 I.L.M. 969).

23 In terms of this, COP 3 "Their sustainable utilization for the benefit of humankind in a way compatible with the maintenance of the natural properties of the ecosystem.” COP 3 of Ramsar Convention, 1987, Recommendation 3.3.

24 COP 3 Ramsar Convention defines sustainable use as "Human use of a wetland so that it may yield the greatest continuous benefit to present generations while maintaining its potential to meet the needs and aspirations of future generations". Recommendation 3.3, COP 3 of Ramsar Convention, 1987.

25 COP 9 states that "[w]ise use of wetlands is the maintenance of their ecological character, achieved through the implementation of ecosystem approaches, within the context of sustainable development". See, paragraph 2, resolution IX.1 Annex A, COP 9, 2005.

26 COP 9 states that "ecological character is the combination of the ecosystem components, processes andbenefits $1 /$ services that characterise the wetland at a given point in time". See Paragraph 15, Resolution IX.1 Annex A, COP 9, 2005. Besides that, paragraph 16, Resolution IX.1 Annex A COP 9 of 2005 at paragraf 16 stated that, at any given time is the time when a state determines that a wetland in the region is an area of protected wetlands (Ramsar site). Furthermore, Resolution IX.1 Annex A COP 9 in 2005 at paragraph 19 states that the ecological character changes (change in the ecological character of wetlands) is produced by human changes that adversely affect the components, processes, and ecosystem benefits.

27 Ibid., pp. 200-201. 
tional conventions that develop so far have been quite to reveal the increase attention of the world community towards sustainable resource utilization and rational, which in turn has also fosters a desire to strengthen the instruments national and international laws concerned with conservation. ${ }^{28}$ Hopefully this increased interest and desire will soon produce standards and norms of international law that is strong enough to achieve the conservation and sustainable use.

\section{b) Sustainable Use in Economic Per- spective}

Bell and McGillivray states that there are at least two conflicting interpretations of the meaning of Sustainable Development. ${ }^{29}$ The first interpretation of sustainability is "strong sustainability". This view holds that the natural resource is something that is not replaceable, in the sense that the reduction or loss of these resources will not be compensated. Interpretation of sustainability as it gets a lot of criticism for being too emphasizing the importance of the integrity of natural resources, so that any form of development, all this development which has an impact on the environmental conditions, will be resisted.

In view of the strong sustainability, environmental degradation cannot be justified, although this deterioration will be compensated by an increase in capital artificial (human-made capital). In simpler language, environmental damage cannot be justified even though the environmental damage will result in an increase in welfare. On the other hand, environmental activists also reject the view that the natural capital, such as natural resources, capital can be substituted with artificial (man-made capital). For example, primary forests harvested for commercial purposes cannot be replaced by an artificial forest as a result of the commercialization. ${ }^{30}$

Thus, strong sustainability argues that future generations should not be inherited poor environmental conditions, although these conditions on the other hand are able to provide economic wealth to the present generation and the generations in the future. The second interpretation, sustainability is "weak sustainability". In view of the weak sustainability, natural capital ${ }^{31}$ can be exploited throughout the results of this exploitation can be offset by an increase in human capital, such as skills, knowledge, and technology, as well as capital raising artificial (human-made capital), such as infrastructure. In this view the overall capital (total capital) is Natural Capital was added Cultivated Capital Natural Capital, Human Capital, and Human-made Capital. ${ }^{32}$ Throughout the total capital from time to time the amount increases, or at least not reduced, then the development is considered sustainable.

The outlook of weak sustainability sees a trade-off between capital natures with

28 Ibid., p. 199.

29 S. Bell dan D. McGillivray, 2000, Environmental Law: the Law and Policy Relating to the Protection of the Environment, 5th ed., Blackstone Press, London, p. 44. Compared with D. Hunter, et al., which illustrated the existence of 4 versions understanding of the environmental sustainable namely: "weak sustainability", "intermediate sustainability" (which states that in addition must keep the level of integrity capital, we also pay attention to composition from itself, they are natural resources, manufacturing, and human "strong sustainability", and "absurdly strong sustainability" (that depletion of natural resources are not renewable should not experience the slightest, while it cannot be consumed only to an annual growth rate of these resources). See David Hunter, et al., 1998, International Environmental Law and Policy, Foundation Press, Minnesota, pp. 136-137. Based on economics, the difference between weak and strong sustainability lies in the question whether the resource can be replaced with man-made resources. In the opinion of weak sustainability, natural and artificial resources are two things that can be substituted. It means that natural resources can be exploited throughout the results of this exploitation is allocated for the construction of artificial natural resources whose value is equal to or greater than by exploitation of natural resources is done.

30 Sharon Beder, Op.cit., p. 88.

31 Natural capital includes all aspects of natural capital that can be used by humans, including minerals, potential biological resources, and the capacity of the environment to absorb pollution. Included in the definition of this natural capital is "cultivated capital", i.e. natural resource that has undergone a transformation and adaptation by humans, such as cattle and the cultivated plants. Ibid., p. 85. 
artificial capital/human. It means that the natural resources available today can be consumed or "sacrificed" if it is more profitable compared to not consume these resources, when the supply of natural resources provided for future generations do not experience a reduction. In between natural capital sand man-made capital it is interpreted to have the same value, so we do not have to worry about the loss of environmental resources for a human to create instead of equal value or better.

This view of weak sustainability is often associated with the perspective of neoclassical economics ${ }^{33}$ which saw sustainability as a restriction (constraint) which is applied to the efforts of maximizing the quality of the environment of the current generation. In this view, the restriction will be directed to the availability of natural capital which is not declining (non-declining stock of natural capital). ${ }^{34}$ The availability of natural capital consists of: (a) System availability supports ecological carrying capacity; (b) Biodiversity; (c) Renewable natural resources; and (d) Non-renewable natural resources. Since the depletion of non-renewable natural resource availability is inevitable, then the sustainability of the utilization of non-renewable natural resources needs to minimize the consumption of non-renewable natural resources accompanied by the replacement of the natural resources with renewable natural resour- ces in sufficient quantities which are above the number available at this time. ${ }^{35}$

In general, economists usually consider the quality of the environment as one commodity among other commodities. Thus, considering that condition and assuming the limitations, so the improvement of environmental quality can only be done by reducing the production of other commodities. Vice versa, an increase in other commodities will be achieved with the consequences of environmental degradation. This relationship is often portrayed in the production possibilities curve, which reflects the tradeoff between environmental quality and the production of commodities. In an economic perspective, the production curve shows the Pareto-optimal conditions, the aggregation of individual preferences toward environmental quality which will be faced with the need for commodity production. Environmental policy, therefore, is an attempt to maximize the standard of living to remain on the production curve. ${ }^{36}$

The view of the flow of neo-classical economists over often been criticized for several reasons. Some of the criticisms raised by Smith, namely: Firstly, neo-classical economic views are often biased towards efficiency, and ignore the aspect of fairness in development. In this case, the issue of fairness is often considered non-economic

33 Broadly, Smith describes the neo- classical economist view as follows. Firstly, neo-classical economists split weighting issues into two categories: efficiency in the issue of wealth maximization (societal wealth), and justice, namely the issue of wealth distribution. Secondly, this view assumes that in a perfectly competitive market, the market mechanism will work based on the actions of market participants are rational and self -interested (only thinking of himself). In this condition, the market will work perfectly, and lead to an efficient allocation of resources (allocated efficiency) based on Pareto -optimality, which is a condition where a person is no longer able to be better (better off) without making someone else worse (worse off). Hypothetically, an efficient allocation is achieved at the point of tangency between the production of possibility curve (production -production curve) of the producer, the utility possibility curve utility -possibility curve) of consumers. Thirdly, if the price of an item does not exist or is not reflected in the market, then the neo- classical economists typically use a "shadow price". By this way, then the economists can estimate the "price" of biodiversity, clean air, clean water, and a variety of other public goods , the actual price cannot be found in the market. Fourthly, neo-classical economists also usually using the "discounting" to obtain the present price of an effect or condition that will occur in the future. Fifthly, generally neo- classical economists give advice on environmental issues such as government intervention, either in the form of the instrument set and monitor (command and control), giving the incentives / disincentives, to the deregulation and the creation of private ownership. Susan L. Smith, "Ecologically Sustainable Development: Integrating Economics, Ecology, and Law", Willamette Law Review, Vol. 31, 1995, pp. 288-290.

34 Ibid., p. 283

35 Ibid., p. 284

36 Ibid. 
issues, but it is a sociological or ethical issue, so it is not a matter for economists. ${ }^{37}$ Secondly, focus on the efficient allocation of resources often encourage policies that focus on increasing production regardless of whether the resulting production meets sustainability or not. In other words, Pareto efficiency does not ensure sustainability. This means that the economic system is based on the assumption of operation of the market perfectly and the existence of perfectly price anyway, not necessarily in line with the need to protect natural resources, ironically, determine the sustainability of economic production itself. ${ }^{38}$ Thirdly, the calculation of the level of pollution or depletion of natural resources are "optimal" path which is usually obtained by reducing (discounting) the interests of future generations. In this case, Smith's example illustrates that the discount rate (discount rate) of 8 percent, then the value of the interests of future generations is reduced to only one-tenth of the interests of the current generation. ${ }^{39}$ Fourthly, since it treats the environment as a commodity, neo-classical economic models fail to pay attention to the uniqueness of the environment. In this context, the character of cumulative and synergistic effects of human activities on the environment carrying capacity is not certainly in line with the marginal analysis and environmental divisible assumptions applied in the neo- classical models. On the other hand, many public goods, such as air or water, are not necessarily appropriate when treated as private property, so it is not necessarily also suitable to be placed within the framework of resource allocation according to Pareto. In addition, there are many natural resources whose value cannot be replaced, so that shrinkage or damage is irreversible (irreversible) ${ }^{40}$ Fifthly, neo- classical view fails to pay attention to the intrinsic value of the environment. ${ }^{41}$ In this case, it can be said that the neo-classical view of the orientation is to increase the utility of human, so it can be said to be very anthropocentric.

Thus, the weak sustainability view also has various drawbacks which make this view often different from the concept of development adopted before the familiar concept of Sustainable Development. The second view is therefore considered as a concept that is "empty". Some economists then try to provide a middle ground of the two definitions of sustainable development at the extreme top of the top. Jacobs, for example, interpret sustainable development as development that is able to protect the capacity of the environment to avoid future disasters, as well as to ensure that future generations enjoy the benefits of environmental resources is the same as the current generation. According to him,"sustainability means that the environment should be protected in such a condition and to such a degree the environmental capacities (the ability of the environment to perform its various functions) are maintained overtime: at least at levels sufficient to avoid future catastrophe, and at most at levels which give future generations the opportunity to enjoy an equal measure of environmental consumption." ${ }^{\prime 2}$

Meanwhile, as the response to the flow of neo-classical economic environment, some economists initiated a sect of thought called ecological economics. This stream interprets sustainable development as a protection against critical natural capital, which is a critical natural resource. In this context,

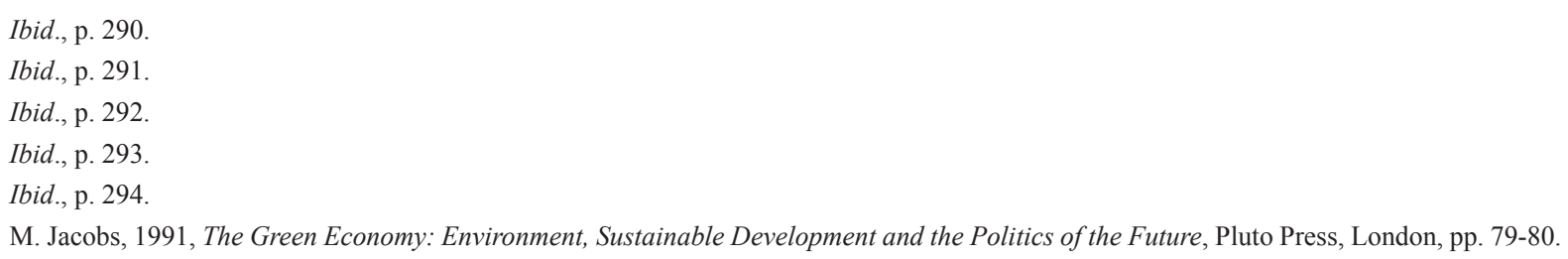


Constanza and Daly stated that sustainable development includes the construction of several principles. Firstly, the main principle of sustainable development is an attempt to limit the impact of activity (economic) in order to at least still be within the limits of the carrying capacity of natural capital that exist. If the carrying capacity limit has been reached, then at the same time needs to be set selection of population-level patterns and living standards (level of resources per capita consumption) certainly. Sustainable development should therefore be at the same time efficient and sufficient. Secondly, advances in technology should be focused on improving the efficiency, and not on increasing the use of natural resources (throughput-increasing).

Thirdly, renewable natural resources, both in function and as a source of material as well as sinks (sinks) must be used with the goal of profit maximization sustainably. The availability of renewable natural resources must be maintained, because this resources will be more important when the availability of natural resources, both renewable and non-renewable, experienced shrinkage. This means that the rate of utilization of renewable natural resources (harvesting rate) must not exceed the rate of regeneration of the resource. On the other hand, the release of waste may not exceed the environment's ability to accommodate and process the waste (the renewable assimilative capacity of the environment). Fourthly, non-renewable natural resources can be utilized, but the utilization rate should be equal to the rate of creation of renewable substitutes. Therefore, project resource utilization of non-renewable (nonrenewable projects) must be balanced with project creation and utilization of renewable resources. Thus, soon we are able to create renewable substitutes (renewable substitutes) over non-renewable natural resources, and the longer lifespan (life expectancy) of non-renewable natural resources, namely the amount of reserves divided annually, then the less resources non-renewable natural to be reserved. It means that the level of reserves of non-renewable natural resources is based solely on the level of creation and utilization of this resource substitution, and the rate of depreciation of these resources relative to its availability. Constanza and Daly interprets the word "substitution" broadly, which also includes systemic adaptations (systemic adaptation), namely the ability of the economy to adjust to the shrinkage of natural resources that cannot be updated. The purpose of this adjustment is to ensure that future income is at least equal to the level of current income (to maintain future income at present levels). ${ }^{43}$

Furthermore, Constanza and Daly, as quoted by Common and Stagl, also filed two minimum conditions for the validity of sustainable development as the protection of critical natural capital. According to them, a development said to be sustainable if it is able to undertake the protection of the natural resources that are already in critical condition. Under these conditions, sustainable development by way of: ${ }^{44}$ (a) Renewable natural resources can only be exploited to the extent that efficient. Thus, the purpose of continuously development is the efficient use of natural resources. (b) The exploitation of non-renewable natural resources must be in re-investment for the recovery of renewable natural resources.

The question, of course, is how we can determine that the exploitation of renewable natural resources that we are doing is efficient. In ideal conditions, of course we have to rely on science that is available to determine to what extent and what the renewable natural resource exploitation to be carried

43 Robert Costanzadan Herman E. Daly, "Natural Capital and Sustainable Development”, Conservation Biology, Vol. 6, No. 1, 1992 , p. 44.

44 M. Common and S. Stagl, 2005, Ecological Economics: An Introduction, Cambridge University Press, Cambridge, p. 378. 
out. Nevertheless, science is often difficult to determine the exact level of exploitation that may be performed. In addition, we often find that science, which is especially in the case of economic interest requires in natural resource management, no longer can one vote. When science becomes full of uncertainty, filled with different values, and are susceptible to a variety of interests, then science can no longer be considered neutral. These conditions by Functowicz and Ravetz referred to as post - normal science.

According Functowicz and Ravetz, in situations of post - normal science, public policy can no longer be entirely left to the experts. On the contrary, it emphasizes the importance of transparency and public participation, including the participation that is not from the experts, in the decision making process. ${ }^{45}$ In short, we can refer to the opinion of a British economist, P. Anand, "if decisions have to be made under conditions of substantial uncertainty, then decision analysis indicates that people should be consulted about their values". ${ }^{46}$

In line with the need for public participation and greater transparency in public policy-making, in the last few decades has developed a new principle of environmental law, namely the precautionary principle. In this context, the principle of the utilization of renewable natural resources is manifested, for example, in the Safe Minimum Standard (SMS), the minimum safety standards.

According Ciriacy-Wantrup, SMS is applied to avoid the use of natural resources in the "critical zone", which is a physical condition that is generated by human activities, where the recovery of reserves depletion of natural resources economically is no longer possible. ${ }^{47}$ This is because although certain natural resources, such as forests, can be said to be renewable, but if the exploitation of natural resources has passed the "critical zone", then society at large must bear the substantial economic burden to restore the backup to the use of natural resources in the future. In other words, the use of SDA in the "critical zone" has resulted in irreparable, irreversible. ${ }^{48}$ Consequently, they who want to perform the utilization of natural resources have the burden to prove that the utilization of natural resources shall not exceed the minimum safety standards.

\section{Conclusion}

Sustainable development as defined by the WCED can be lowered into the four elements, namely the principle of integration, sustainable use, intra-generation equity, and inter generations equity. This article has been discussed in detail the principle elements of integration and sustainable use. Each discussion is not only done by mere legal perspective, but also has used a non-legal analysis, especially the debate of ethical and economic terms. Discussion on the non-legal of these aspects that have enriched the analysis in this article, so it enriches the analysis related to the development, debate, interpretation, thus enriching the analysis related to the development, debate, interpretation, even the application of any element of sustainable development. The principle of integration as a unifying backbone and other elements of sustainable development have the function as a rule that connect the various interests and principles that may be mutually exclusive. However, as has been shown in this article, the principle of integration cannot be interpreted as a perspective that puts all the requirements in the interests of the same weight. In contrast, the principle of integration it should be placed in the shells of sustainability and protection of the essential ecological functions. Thus, the application of the principle of integration requires the

J. Ravetz, "The Post-Normal Science of Precaution", Futures, 2003, pp. 7-8

P. Anand, "Decision-Making when Science is Ambiguous", Science, Vol. 295, March 2002, p. 1839.

S.V. Ciriacy-Wantrup, 1952, Resource Conservation: Economics and Policies, University of California Press, California, p. 253.

48 R.C. Bishop, "Endangered Species and Uncertainty: the Economics of a Safe Minimum Standard", American Journal of Agricultural Economics, Vol. 60, 1978, p. 10. 
priorities, where the protection of the essential ecological functions is a priority of the integration and balancing various needs. Sustainable use although it has been defined and described in various terms, ranging from sustainable use up to the maximum sustainable yield (MSY) or optimum ecological resource management (OERM). The extent to which international law has defined an obligation to do the conservation and sustainable use of course cannot be determined at this time. In fact, in addition to the terms used are different, not many of the conventions that have been able to develop a regime that is specific enough to apply the concept of sustainable use. Most conventions are usually still gives each state the authority and discretion are very large and decisive in translating the conservation and sustainable use. However, with all these limitations, an optimistic outlook still see that commitments and international conventions have evolved far enough to indicate an increase in the attention of the world community towards sustainable resource utilization and rational, which the recent has also fosters a desire to strengthen the instruments national and international laws related to conservation.

From a non-legal perspective, the debate about the sustainable use is usually associated with differences interpretation in the meaning of sustainability. In this case, generally we see a difference in emphasis and interpretation of a group of weak sustainability, strong sustainability, and sustainability as the protection of critical natural capital. In addition, efforts in sustainable use can economically also be associated with efforts to provide a safe limit for the rate of exploitation of natural resources, which is often referred to as the safe minimum standard.

\section{REFERENCES}

\section{A. Book}

Beder, Sharon, 2006, Environmental Principles and Policies: An Interdisciplinary Introduction, Routledge, London.

Bell, S. dan D. McGillivray, 2000, Environmental Law: the Law and Policy Relating to the Protection of the Environment, Blackstone Press, London.

Birnie, Patricia, Alan Boyle, dan Catherine Redgwell, 2009, International Law and the Environment, Oxford University Press, Oxford.

Ciriacy-Wantrup, S.V., 1952, Resource Conservation: Economics and Policies, University of California Press, California.

Common, M. and S. Stagl, 2005, Ecological Economics: An Introduction, Cambridge University Press, Cambridge.

Fitzmaurice, Malgosia, 2009, Contemporary Issues in International Environmental Law, Edward Elgar, Camberley.

Hunter, David, et al., 1998, International Environmental Law and Policy, Foundation Press, Minnesota.

Jacobs, M., 1991, The Green Economy: Environ- ment, Sustainable Development and the Politics of the Future, Pluto Press, London. Sands, Philippe, 1995, Principles of International Environmental Law: Vol. 1, Frameworks, Standards, and Implementation, Manchester University Press, Manchester.

Ravetz, J., 2003, The Post-Normal Science of Precaution, Futures.

Voigt, Christina, 2009, Sustainable Development as a Principle of International Law: Resolving Conflicts between Climate Measures and WTO Law, Martinus Nijhoff Publishers, Leiden.

\section{B. Journal Articles}

Anand, P., "Decision-Making when Science is Ambiguous", Science, Vol. 295, March 2002.

Barral, Virginie, "Sustainable Development in International Law: Nature and Operation of An Evolutive Legal Norm", European Journal of International Law, Vol. 23, No. 2, 2012.

Bishop, R.C., "Endangered Species and Uncer- 
tainty: the Economics of a Safe Minimum Standard", American Journal of Agricultural Economics, Vol. 60, 1978.

Costanza, Robert and Herman E. Daly, "Natural Capital and Sustainable Development", Conservation Biology, Vol. 6, No. 1, 1992.

Marong, Alhaji B.M., "From Rio To Johannesburg: Reflections on the Role of International Legal Norms in Sustainable Development", Georgetown International Environmental Law Review, Vol. 16, 2003.

Meyers, Gary D. dan Simone C. Muller, "The Ethical Implications, Political Ramifications and Practical Limitations of Adopting Sustainable Development as National and International Policy", Buffalo Environmental Law Journal, Vol. 4, 1996.

Osofsky, Hari M., "Defining Sustainable Development After Earth Summit 2002", Loyola of Los Angeles International \& Comparative Law Review, Vol. 26, 2003.

Smith, Susan L., "Ecologically Sustainable Development: Integrating Economics, Ecology , and Law “, Willamette Law Review, Vol. 31, 1995.

\section{Anthology}

Magraw, Daniel Barstow and Lisa D. Hawke, "Sus- tainable Development", in Daniel Bodansky, Jutta Brunnée, and Ellen Hey (Eds.), 2007, The Oxford Handbook of International Environmental Law, Oxford University Press, Oxford.

\section{Decision}

Case Concerning the Gabcikovo-Nagymaros Project (Hungary v. Slovakia): Separate Opinion of Vice-President Weeramantry, 1997 ICJ 7.

Case Concerning Pulp Mills on the River Uruguay (Argentina v. Uruguay), Separate Opinion of Judge Cançado Trindade, 2010.

\section{E. Report}

World Commission on Environment and Development, 1987, "Report of the World Commission on Environment and Development: Our Common Future", Report.

\section{F. Treaties/Conventions}

Rio Declaration, Doc. A/CONF.151/26 (vol. I), 31 ILM 874 (1992) (hereinafter called Rio Declaration).

Convention on Biological Diversity 1992 (1760 UNTS 79, 31 ILM 818).

Ramsar Convention 1971 (996 U.N.T.S. 245, 11 I.L.M. 969). 